\title{
Virus-Induced Changes in Neural Cells
}

\author{
Erik Lycke
}

\section{INTRODUCTION}

Virus infections of the CNS have attracted particular interest not only because of their medical importance but also because of the unique features that infections display within a compartmentalized and highly specialized organ system such as the CNS. To reach the CNS, the virus must overcome or circumvent the anatomical and physiological barriers of the CNS. Once inside the CNS, there seems to be no CNS intrinsic immune system activated but a recruitment of macrophages and an invasion of immune-competent and phagocytic cells. Immune reactions are probably crucial for clearance of virus from the infected CNS but they may also be involved in disease-associated reactions. Although most clinically manifested virus infections tend to become generalized, and virus infections of the CNS therefore may represent the result of a systemic spread of the infection, some viruses demonstrate a greater affinity for neural cells than others and exhibit neurotropic properties. The present chapter presents various aspects of virus-nerve cell interactions, but as information in particular at the molecular level is still very limited, it has been necessary for a more complete presentation to add some relevant observations on viral effects on nonneural cells.

\section{NEUROTROPIC VIRUSES}

The concept of tropisms, repeatedly challenged, has regained credibility with growing knowledge of viral pathogenesis. Neurotropism might be regarded as reflecting a summation of multifactorial influences of which the presence of receptors on neuronal cells for attachment of a virus appears to be one. Permissiveness of nerve cells to a virus infection and cytocidal effects of the in-

Erik Lycke - Department of Virology, Institute of Medical Microbiology, University of Göteborg, 41346 Göteborg, Sweden. 
fection, including those evoked by immune reactions against infected cells, are other factors decisive for the appearance of clinical manifestations. These might depend on degeneration and death of neurons or on metabolic and functional changes of infected but still vital neural cells. The variability in the outcome of the infection has generally been attributed to factors extrinsic to the nervous system, e.g., the dose of infecting virus, the virulence and other genetic properties of the virus, and the defense mechanisms of the host. However, the functional and metabolic state of the neural cells might be equally important in determining the course of infection. The medical implications of neural cell dysfunctions as consequences of latent or past virus infections have not been closely examined.

Neurotropism is difficult to define. To comply with conditions of neurotropism in very restricted terms, one may assume that the pathogenesis of infection should reveal the specific interactions of virus and neural cells that monitor the course of the infection. With this presumption it is doubtful that most viruses that reach the CNS by hematogenous spread and after infection of meningeal and ependymal cells might be referred to as neurotropic since the CNS involvement in many of these infections mainly reflects the generalization of the infection. Infection of the neuronal cells is preceded by infection of vascular endothelial cells and glia and by migration of infected white blood cells into the CNS. The CNS infection reveals that the immune defense has not been able to compete in the race against the infection. It would be preferable to consider those viruses that reach the CNS by neural routes and that are spread within the CNS by neuronal pathways as more strictly neurotropic. However, this kind of distinction is by no means unequivocal since it is obvious that, for example, transmission of infection within the CNS also might depend upon diffusion of virus into the intercellular space from degenerating infected neurons, or be mediated by the inflammatory response. Moreover, it is difficult to discriminate infections reaching the CNS by axonal transport from those that infect neurons via satellite cells and glial cells.

Most of the virus-cell interactions and virus-induced changes of metabolic and functional states of infected neurons described in the following refer to findings with three virus families, i.e., the herpes-, paramyxo-, and rhabdoviruses. Short descriptions of these viruses are presented below. Comprehensive reviews on pathogenesis of virus infections of the nervous system have recently appeared. ${ }^{1-6}$

\subsection{Herpesviruses}

Of the approximately 70 herpesviruses, 6 are pathogenic for man [herpes simplex virus (HSV) types 1 and 2, cytomegalovirus, varicella-zoster virus (VZV), Epstein-Barr virus (EBV), and herpes B virus]. Some herpesviruses display biological properties making them characteristic representatives of neurotropic viruses. The herpesviruses are ubiquitous, causing as a rule subclinical infections but may occasionally develop into life-threatening infections. Infections with herpesviruses regularly lead to establishment of latent reactivatable infections of particular target cells. Of these, not only sensory neurons of dorsal 
root ganglia but also other neuronal cells have been shown to harbor latent infections with HSV and VZV.

Most interactions of herpesviruses and neuronal cells have been studied experimentally as well as clinically with HSV. The virions of HSV have an icosahedral nucleocapsid made up of 162 capsomeres. The 100 -nm nucleocapsid is surrounded by an envelope, giving the virion a total diameter of 150-200 $\mathrm{nm}$. The genome is a linear double-stranded DNA molecule with a molecular weight of $10^{8}$. Theoretically, the HSV genome might code for up to 100 different polypeptides. Of these, about 50 proteins have been identified and half of them are referred to as viral structural proteins. The 7 glycoproteins of the envelope have been studied in some detail. Glycoprotein B seems important for penetration and fusion processes between the virion and the plasma membrane. $\mathrm{gC}$ carries type-specific antigenic characteristics immunologically differentiating the two subtypes (HSV-1 and HSV-2) and is, like gD, probably involved in attachment reactions binding the virion to the plasma membrane of the cell. $\mathrm{gE}$ has the capacity to combine with the Fc fragment of IgG immune globulin (the Fc receptor). The occurrence of at least two other HSV-induced glycoproteins has been noted. The envelope glycoproteins are synthesized late during the infectious cycle and also appear to be inserted in the plasma membrane of the infected cell where they constitute major immunogenic proteins. The nucleocapsids are enveloped by a budding process through the inner layer of the nuclear membrane. This maturation process also occurs in neuronal cells and might be important for the mode of transport and release of virus synthesized.

Latent HSV infections have been demonstrated in neurons of peripheral ganglia (cranial, spinal, and autonomic nerves) and in the CNS. During the latent infection, viral replication is restricted. Presence of viral DNA in latently infected cells is demonstrable by nucleic acid hybridization, and transformation of the latent infection to a virus replicative phase has been demonstrated by reactivation of virus in cocultivation experiments in vitro, culturing latently infected ganglionic tissues with permissive indicator cells. Participation of both cellular and viral genes is involved in establishment and maintenance of latency. It is not known if parts or all of the viral genome are integrated with cellular genes. At least a minor part of the virus genome seems to be transcribed in latently infected neurons but the gene products have not been identified. One of the HSV-derived proteins discussed in this context is an immediate-early viral protein, VP175. However, establishment of latent herpesvirus infections seems to be dependent on the ability of the nerve cell to restrict the virus infection rather than due to specific genetic viral characteristics.

Three principally different sets of reactions leading in vivo to reactivation of latent infections in trigeminal ganglia are discernible: peripheral injuries directed against the skin and/or the nerve of the corresponding dermatome (surgical operations or damage caused by trauma, irradiation, chemicals, etc.); centrally induced stimuli often of emotional character (distress, anxiety, depression, etc.); and changes in hormonal status (associated with the menstrual cycle, medication, etc.). It is likely that reactivation frequently occurs in patients with recurrent herpesvirus infections but that intervening immune reactions as a rule prevent the appearance of clinically overt symptoms. 


\subsection{Paramyxoviruses}

Several members of the paramyxoviruses are infectious for neural cells. Thus, infections with parainfluenza virus, mumps and measles virus have all been associated with acute and/or chronic diseases of the CNS in man, canine distemper virus and canine parainfluenza virus with neurological diseases in dogs, and Newcastle disease virus with CNS infections in birds. In experimental animals, acute measles virus infection of the CNS seems primarily to involve oligodendroglia and neurons, although there are marked differences in resistance to infection between neurons of different parts of the CNS. Replication of measles virus in the brain is restricted. Virus is probably spread by cell-to-cell transmission and through dendritic extensions. In certain experimental animals, chronic CNS infection with measles virus demonstrates features that are similar to what has been observed in chronic measles virus infection of the CNS in man, i.e., subacute sclerosing panencephalitis (SSPE). This fatal neurological disease, which occurs in 1 per million children, is probably acquired before the second year of life; the symptoms of disease may become detectable by the beginning of the school age period. The SSPE infection of the CNS seems restricted and is therefore asymptomatic for a long period. However, the infection persists and is influenced, but not cleared from the CNS, by immune reactions. When extensive pathological changes have been created, the disease becomes clinically apparent. Virions are not seen budding from plasma membranes of infected neural cells, and as signs of restriction of viral replication, infectious virus is demonstrable only by cocultivation of brain specimens with measles virus-permissive cells.

The paramyxoviruses demonstrate virions that are pleomorphic (100-300 $\mathrm{nm}$ ) with an enveloped nucleocapsid of helical structure and a single-stranded linear RNA genome with a molecular weight of $6 \times 10^{6}$. Six viral proteins are recognized. The matrix $(\mathrm{M})$ protein is present on the inside of the envelope and two glycoproteins are inserted in the lipid layer of the envelope. Of the glycoproteins, the $\mathrm{HN}$ protein carries hemagglutinin and neuraminidase activity and the $\mathrm{F}$ protein participates in fusion reactions with the cellular membrane to which the virion attaches via the NH protein. The protein of the nucleocapsid is referred to as NP. In addition, the nucleocapsid contains two other proteins designated L (large) and P for an RNA-dependent RNA polymerase. After attachment and fusion of the virion with the host cell, the RNA is transcribed by the polymerase of the nucleocapsid. The glycoproteins are glycosylated by cellular glycosyltransferases and are inserted in the plasma membrane of the infected cell where they are demonstrable as viral antigens. Virions are produced by budding from the modified plasma membrane. Measles virus lacks neuraminidase activity and does not-like the neuraminidase-supplied paramyxoviruses-exclude sialyl groups from the plasma membrane of infected cells.

\subsection{Rhabdoviruses}

Both rabies virus and VSV cause CNS disease and in rabies the selective involvement of neuronal cells is striking. Infection with rabies virus in man 
causes an acute lethal CNS disease and although virus also replicates in several different tissues, the course of the infection and the symptomatology are determined by the virus-nerve cell interactions. Rhabdoviruses are large (175 $\times 70 \mathrm{~nm}$ ) negative-stranded RNA viruses. For RNA transcription, the virion carries an RNA-dependent RNA polymerase in the nucleocapsid. The helical nucleocapsid is covered with an envelope containing approximately 500 copies of a glycoprotein $(G)$ that is essential for virion attachment to cells. As the $G$ protein is glycosylated, the $G$ protein and the $M$ protein are located on the surface of the nucleocapsid to which the $G$ protein is anchored. Like most other viral glycoproteins, the $\mathrm{G}$ protein appears to be inserted in the plasma membrane of infected cells.

In rabies-infected nerve cells, the morphogenesis of the virus occurs inside the cell in the endoplasmic reticulum, whereas in nonneuronal cells, rabies virus, and VSV, buds out from the plasma membrane. The possible influences on the axonal transport and the release of virions from infected neurons when the morphogenesis of rabies virus is intracellular have not been evaluated.

The relatively long incubation time of rabies seems largely dependent on slow production of virus in muscle cells preceding the nerve cell infection. In the CNS, virus is spread and replicated selectively by neuronal cells. Both clinical symptoms and histopathological findings suggest that certain areas of the brain (particularly structures of the limbic system and the cerebellum) are affected. Later, virus reappears in muscles, abdominal organs, skin, and other tissues. The relative independence of engagement of cellular elements other than nerve cells is reflected in the insignificant inflammatory reactions.

\section{VIRAL RECEPTORS ON NEURAL CELLS}

The perineurium, which acts as a diffusion barrier, does not totally encapsulate the motor and sensory terminals but terminates before it reaches the synaptic cleft or the nerve terminal, leaving the nerve open-ended. ${ }^{7,8} \mathrm{Near}$ the plasma membrane of sensory nerve terminals, the portion of the terminal area sometimes designated the receptorplasm, endocytotic activity is high with uptake of low-molecular-weight matter as well as exogenous macromolecules. ${ }^{9}$ The endocytotic activity is assumed to be a part of the mechanism for plasma membrane retrieval ${ }^{10}$ or to represent activity compensatory to the exocytosis. ${ }^{11}$ The significance of macromolecular uptake in nerve terminals and the axonal transport have been discussed recently. ${ }^{12,13}$

The mechanisms of macromolecular uptake vary from the seemingly nonspecific (e.g., horseradish peroxidase) to the highly selective (e.g., nerve growth factor). It is not known if neuronal uptake of viruses always requires the presence of specific virus-binding receptors. It is reasonable to assume, however, that viruses and viral subunits may be incorporated by endocytotic activity of the nerve terminal even in the absence of viral receptors. Whether the processing of the virus and the outcome of the infection are different from infections that occur when virus internalization is preceded by interactions between virions and specific virus-binding receptors is not known. 
Since the virus infection of the cell is initiated by attachment of the virion to the plasma membrane, presence, localization, and density of virus-binding receptors on plasma membranes might be decisive for the relative affinity between viruses and cells of a particular organ system. The fact that nerve terminals and synapses are amply supplied with glycoconjugates containing sialyloligosaccharides and that glycoproteins and gangliosides carry functions of biologically important surface membrane receptors suggest that interest should be focused on glycoconjugates selectively concentrated in terminals of neuritic extensions.

A multitude of various cells of most species studied exhibits receptors to which HSV adsorbs. Nevertheless, these receptor reactions reveal a considerable degree of specificity since they can differentiate between the HSV subtypes and specifically bind either HSV-1 or HSV-2. ${ }^{14}$ Blocking of receptors selectively binding HSV-1 with homologous virus does not affect the attachment rate of HSV-2 but excludes the adsorption of HSV-1. Also, nerve and glial cells of brain tissue ${ }^{15}$ as well as ependymal cells ${ }^{16}$ of different species demonstrate HSV-binding receptors. In man, monkey, rabbit, and rat, neuronal receptors with affinity for HSV-1 predominate, but there seems to be an uneven distribution of the receptors along the nerve cell plasma membrane. Synaptosomal fractions of brain tissue contain HSV-adsorbing receptors in abundance whereas the viral receptors seem not at all or only sparsely scattered on the neuronal perikarya. ${ }^{17}$ Therefore, the entry of HSV into the CNS might be monitored by the relative access to receptors present in sensory nerve endings and synapses. In agreement, in vitro cultured rat sensory neurons exposed to HSV become infected via their neuritic extensions without displaying signs of infection such as retraction. ${ }^{18}$ Chemically, HSV-binding cellular receptors are considered to be of glycoprotein nature, and to react with one or more of the viral envelope glycoproteins. ${ }^{19,20}$ Attachment of HSV is promoted by thyroid hormone ${ }^{21}$ and inhibited by parathyroid hormone. ${ }^{22}$

The use of lectins has suggested that concanavalin A binds to HSV but does not interfere with the adsorption of virus to cellular receptors. ${ }^{23-25}$ If the lectin is added together with the virus to rat sensory neurons in culture, HSV is rendered noninfectious, ${ }^{25}$ presumably by destruction of virions. After treatment of cultures of rat sensory neurons with various lectins, wheat germ agglutinin (WGA) and Ricinus communis agglutinin consistently blocked the infection of the neurons apparently by interfering with attachment of HSV to neurites. ${ }^{25}$ Preincubation of HSV with $N$-acetylneuraminic acid but not with $\mathrm{N}$-acetyl-D-glucosamine or $\mathrm{N}$-acetyl-D-galactosamine reduced the infectivity of HSV for neurites of cultured neurons. WGA is readily taken up by neuritic extensions, ${ }^{26}$ and when labeled, for example, with fluorescein, WGA is recovered in the somas of the neurons. For these reasons, WGA is well suited for studies of the mechanisms of membrane binding and neuronal receptor turnover.

It should be pointed out that the experiments with HSV infection of cultured neurons were performed in a culture system allowing infections of neurites without the access of virus to neuronal perikarya. ${ }^{18}$ The observations suggest that sialoglycoproteins on sensory neurites may constitute a receptor 
structure for HSV. However, it is at present not possible to exclude that the influences on HSV attachment by WGA are due to, for example, nonspecific steric hindrance of the virus-receptor binding or lectin-induced redistribution and internalization of receptors, ${ }^{27}$ nor has the viral specificity of the uptake of virions by neurites in culture been ascertained.

Histopathological studies on animals experimentally infected with rabies virus have suggested that rabies virus enters the CNS via sensory nerve endings of muscle and tendon spindles. ${ }^{28,29}$ Immunofluorescence in rabies virus-infected mice indicated in addition that sites of viral antigens were demonstrable in form and distribution similar to those of acetylcholinesterase (AChE), suggesting that rabies virus might well use motor endplates at neuromuscular junctions for entry into the nervous system. ${ }^{30,31}$ In agreement, a similar pattern of coincidence of viral antigen-positive sites and $\mathrm{ACh}$ receptor sites has been observed with rabies virus-infected cultured myotubes from chicken embryos and with preparations of mouse diaphragms with attached phrenic nerves exposed to rabies virus. ${ }^{31}$ Using electron microscopy, viral particles were observed in close apposition to plasma membrane sites associated with highdensity clusters of ACh receptors. Pretreatment of cultured myotubes with $\alpha-$ bungarotoxin or $d$-tubocurarine reduced the attachment and infection rates drastically as revealed by immunofluorescence and assays of virus adsorption. In contrast, Sindbis virus, an alfa-togavirus lacking the neurotropic properties of rabies virus, demonstrated no affinity for ACh receptors. ${ }^{32}$ As neuromuscular junctions reveal a high density of ACh-binding receptors, the affinity of rabies virus for the $\mathrm{ACh}$ receptor probably represents an important pathogenetic mechanism of rabies virus infection.

Most virus receptors are considered to be of glycoprotein nature ${ }^{20} \mathrm{How}$ ever, Sendai virus, one of the paramyxoviruses, adsorbs well to liposomes containing ganglioside. ${ }^{33,34}$ This finding was initially interpreted as if both glycoproteins and glycolipids naturally might serve as virus receptors. However, treatments with neuraminidase and trypsin, and observations that in glycoconjugate-containing liposomes virtually all of the Sendai virus-binding activity was associated with the glycoprotein rather than with the glycolipid fraction ${ }^{35}$ have emphasized the importance of protein as carrier of the Sendai virus receptor. The identification of the molecular structure of the oligosaccharide receptor was carried further by studies on the binding of Sendai virus to plasticadsorbed gangliosides. It was then demonstrated that the virus adsorbed with high affinity to gangliotetraosylceramides with a terminal disialosyl group. ${ }^{36} \mathrm{~A}$ recognition structure, NeuAc $\alpha 2,8 \mathrm{NeuA} \alpha 2,3 \mathrm{Gal} \beta 1,3 \mathrm{GalNAc}$, was proposed on basis of maximal binding capacity. In agreement, neuraminidase-treated bovine kidney cells, which by the treatment became resistant to infection with Sendai virus, regained susceptibility after a brief exposure to CMP-sialic acid and $\beta$ galactoside: $\alpha 2,3$-sialyltransferase. ${ }^{37,38}$ Moreover, receptor activity and susceptibility to infection were also restored in cells treated with trypsin to remove the original glycoprotein receptor. Treatment of 3T6 cells with neuraminidase renders these cells resistant to polyoma virus but susceptibility to infection can be restored by reacting the cells with $\beta$-galactoside: $\alpha 2,3$-sialyltransferase and CMP-NeuAc, forming the sequence NeuAc $\alpha 2,3 \mathrm{Gal} \beta 1,3 \mathrm{GalNAc}$, which seems 
to be serving as the specific receptor. ${ }^{39}$ The relevance of these observations to viral attachment to neural cells has not been evaluated.

The oligosaccharide moiety of viral glycoproteins are considered responsible for formation and maintenance of the tertiary structure of the peptide constituent and necessary for the function, protection, and transport of the viral protein in the cell. ${ }^{40} \mathrm{HSV}-1$ particles produced in the presence of glycosylation inhibitors (2-deoxy-D-glucose and tunicamycin), and thus lacking $N$ linked oligosaccharides, still demonstrate the capacity to adsorb to cellular receptors. ${ }^{41} \mathrm{HSV}$ adsorption apparently does not require the presence of $N$ linked oligosaccharides in envelope glycoproteins. The nonglycosylated $G$ protein of VSV is not transported to the plasma membrane and no budding of virus is observed. ${ }^{42}$ Measles virus, lacking neuraminidase in the virion, is reported to incorporate NeuNAc into the envelope when virus is budding out from the plasma membrane,${ }^{43}$ but NeuNAc on the envelope glycoprotein does not seem to be essential for attachment. The general impression is that inhibition of glycosylation of viral envelope glycoproteins results in defective production of virions ${ }^{42,44,45}$ but that the carbohydrates of the viral envelopes are of no or insignificant importance in virus recognition of cellular receptors.

\section{AXONAL TRANSPORT OF VIRUSES}

The concept that virus infections may spread of the CNS by the axonal flow of nerves is based on numerous clinical, histopathological, and experimental observations. One of the earliest indications for axonal transport of a virus was the classical experiment of Bodian and $\mathrm{Howe}^{46}$ demonstrating poliovirus retrograde progression along the sciatic nerve of the monkey at a rate estimated to $2.4 \mathrm{~mm} / \mathrm{hr}$ and recovery of the virus from the spinal cord. It is now accepted that virus infections can be transferred axonally, probably in the same way as newly synthesized cellular proteins, i.e., by fast axonal flow. ${ }^{47}$

In herpesvirus infections, axonal transport of the virus is unequivocally demonstrated with HSV and VZV and is probable also in herpes B virus infections of man. In mice infected intradermally, the spread of HSV infection was prevented by ligating, freezing, or colchicine soaking of the sciatic nerve prior to infection..$^{48}$ Ultrastructurally, virions have been observed intraxonally in HSV-infected animals, ${ }^{49,50}$ but it is questionable if the particles detected represent virus traveling from the periphery toward the CNS or virus transported in the opposite direction. If the virions observed were transported with the retrograde flow, there should have been no preceding fusion between the viral envelope and the membrane of the nerve terminal.

Nucleocapsids have also been seen in nonmyelinated axons, ${ }^{49,51}$ but again it is uncertain if these nucleocapsids originate from, for example, leakage through breaks of the nuclear membrane of infected neurons. We have found that HSV-1 infection of neuritic extensions of rat sensory neurons in culture is initiated by fusion of the viral envelope of attached virions with the neuritic plasma membrane. ${ }^{178}$ Subsequently, the infection is axonally transported from the periphery toward the cell soma with the viral nucleocapsids. In turn, virus produced de novo in infected nerve cell bodies is transported in the neuritic 
extensions from the cell soma toward the periphery but now as enveloped virus confined to vesicles.

The in vitro studies failed to demonstrate infectivity of HSV nucleocapsids taken up by neuritic extensions. Because fractions with nucleocapsids produced by heat treatment of HSV suspensions have been reported to maintain infectivity as revealed by transfection experiments, ${ }^{52,53}$ it is unlikely that HSV nucleocapsids that are internalized passively into neurons are able to cause infection.

Rats infected with HSV-1 by microinjection of virus into the left neostriatum demonstrate infected neurons in the substantia nigra, cortex, and dorsal raphe nuclei. ${ }^{54}$ This spread of the infection is compatible with a retrograde transport of the infection from the neostriatum. The massive degeneration of afferent nerve terminals observed throughout the neuropil probably reflects degeneration of nerve cells at distant sites. In fact, in mice infected in the snout, the HSV infection may be followed by the peroxidase-antiperoxidase (PAP) method to the third order of neurons. ${ }^{55}$ Elongated deposits of PAP-reaction products, the length of which might exceed that of a Schwann cell segment, have been found in trigeminal nerve axons. Such accumulations of viral antigens presumably representing material transported with the axoplasmic flow toward sensory endings have also been observed in rabies-infected hamsters. ${ }^{1}$ Of the brain stem, trigeminal sensory nuclei, and trigeminal spinal tract nuclei, and, moreover, the reticular formation including the raphe nuclei, the thalamic nuclei and the locus coeruleus demonstrated the presence of HSV antigens. Thus, the infection had passed two or more synapses on its way to the brain stem. In cultures of dorsal root ganglionic neurons ${ }^{18}$ and autonomic neurons ${ }^{56}$ of the rat, the HSV infection appears to be spread from cell to cell via neuritic extensions without being influenced by antiviral antibody added to the culture overlay medium.

Several reports emphasize the axonal transport of rabies virus. ${ }^{28,29,57-59}$ It has been suggested that after fusion of viral envelope and the plasma membrane, the rabies virus nucleocapsid is transported in the axoplasm. ${ }^{1}$ In accord with the hypothesis of axonal transport, treatment with colchicine or vinblastine of mouse sciatic nerve after virus inoculation prevented spread of the infection to the CNS. ${ }^{58}$

Other evidence, some of which is circumstantial, suggests that rabies infection is transmitted transsynaptically. In this way, nerve cell processes can transfer the virus infection without exposing the virus to neutralizing antibodies and thus facilitating persistence of the infection even in the immune animal. ${ }^{60,61}$ It is possible that budding of virions on axonal membranes of infected neurons occurs, and an intraaxonal accumulation of viral nucleocapsids at nodes of Ranvier has also been noted. ${ }^{1}$

In cultures of dissociated mouse neurons, VSV infection is markedly influenced by addition of antiviral antibodies. In the presence of antibodies, viral nucleocapsids accumulate in dendritic extensions and budding sites are frequent on the side of the postsynaptic density. Viruses seem to enter directly into the lateral side of the presynaptic terminal to which the virus-delivering dendrite is connected. ${ }^{61}$ These findings suggest somatofugal transport of nu- 
cleocapsids and are in agreement which in vivo experiments with rabies-infected animals.

Transsynaptic dissemination within the CNS of measles virus and viral antigens has been visualized by immunofluorescence, immunoperoxidase, and electron microscopy techniques. In measles virus-infected animals, antigens were traced to neuronal perikarya with somatofugal spread into dendritic and synaptic sites. Nucleocapsids and antigenic viral subunits were identified in the nucleus and cytoplasm of the neuron including dendrites at various distances from the cell body. A frequent finding was the presence of viral antigens in postsynaptic endings. ${ }^{62}$

In cases of SSPE, measles virus antigens are widely distributed within the brain. Infected cells demonstrate antigens in both nucleus and cytoplasm, and sometimes in the neuritic processes ${ }^{63,64}$ Of neurons involved, both cortical pyramidal cells and large brain-stem neurons have been observed. ${ }^{64}$ It has been suggested that in SSPE, viral genetic information spreads from cell to cell along dendritic processes. ${ }^{65}$ However, in measles as in rabies, the presence of antiviral antibodies seems important for restriction of the infection to the neuronal cells.

\section{VIRAL PROTEINS IN PLASMA MEMBRANES INFLUENCE NEURAL CELL ACTIVITIES}

Cells infected with enveloped viruses acquire new membrane-active components in association with the fusion process by which the viral envelope merges into the cellular membrane and when viruses become enveloped by budding out from cellular membranes and viral glycoproteins are inserted. ${ }^{66,67}$ Changes in membrane-mediated cellular functions may also occur when viral antigens in membranes of infected cells react with immunoglobulins, causing redistribution of ligand-globulin complexes. ${ }^{68-71}$

Theoretically, virus infections affecting membranes of nerve cells may interfere with, for example, protein transport maintaining functional axonal regions and synaptic terminal membranes. This transport seems predominantly membrane-associated.$^{47}$ The vesicles that constitute the vesiculotubular structures acting as transport vectors within the axon and that become associated with synaptic vesicles at the terminal are, like the viral envelope glycoproteins, Golgi-derived and may be affected by viral glycoprotein synthesis. Insertion of viral glycoproteins in cell membranes may in addition imply exclusion of constituents with receptor functions normally present.

An influence of virus infections on nerve cell receptor functions has been observed with cell line 108-CC-15 (NG-108-15), a mouse neuroblastoma $\times$ rat glioma hybrid, demonstrating a variety of neuronal receptor activities. ${ }^{72}$ Intracellular cAMP levels were likely reduced by membrane receptor changes in cells persistently infected with rabies virus. ${ }^{73}$ Incubation with prostaglandin $\mathrm{E}_{1}$ $\left(\mathrm{PGE}_{1}\right)$, which in the infected hybrid cells is followed by a rapid rise in cAMP levels, was in the rabies-infected cultures followed by an increase that was 
only $50 \%$ of that of the uninfected control. In comparison with uninfected cells, rabies-infected hybrid cells exposed to L-isoproterenol, an adrenergic agonist, and $\mathrm{PGE}_{1}$ revealed impaired $\alpha$-adrenergic receptor functions. In contrast, the ACh receptor functions remained unaffected when cells were exposed to PGE $_{1}$ and $\mathrm{ACh}$. The latter finding may be at some variance with observations on binding to homogenates of rabies-infected rat brain of $\left[{ }^{3} \mathrm{H}\right]$ quinuclidinyl benzylate, an antagonist to the muscarinic ACh receptors. ${ }^{74}$

The binding of the antagonist declines at the time of the appearance of clinical symptoms; whether this is a result of a reduced number of receptors available or due to more complex mechanisms of impaired neuronal function is unknown. Recent observations suggest that the number of opiate receptors on neuroblastoma-glioma hybrid cells persistently infected with rabies virus is not reduced but that instead their binding affinity is decreased..$^{75}$ The reported findings were all obtained with fixed rabies virus strains. In street rabies virus infections, the importance of viral glycoproteins of infected cells is doubtful, since in contrast to infections with fixed virus, only small amounts of viral glycoproteins are present in the plasma membrane of infected neurons. ${ }^{76}$

Established mouse neuroblastoma cells (clone N 115) persistently infected with lymphocytic choriomeningitis virus (LCMV) display maintained receptor functions for $\mathrm{ACh}$ as revealed by their affinity for neurotoxin A and $\alpha$-bungarotoxin. On the other hand, the virus infection causes significantly reduced cellular levels of $\mathrm{AChE}$ and choline acetyltransferase. ${ }^{77} \mathrm{~A}$ similar reduction of AChE activity has been noted in neuroblastoma cells (clone $41 \mathrm{A3}$ ) acutely infected with measles virus. ${ }^{78}$

Failure of another mouse neuroblastoma cell line (clone $\mathrm{N}_{2} \mathrm{~A}$ ) to manifest signs of neural differentiation when persistently infected with measles virus was considered to be related to impairment of receptor-mediated cAMP synthesis. ${ }^{79}$ The reduction of $\mathrm{AChE}$ formation in $\mathrm{N}_{2} \mathrm{~A}$ cells persistently infected with measles virus was associated with a general decrease of RNA and protein synthesis. It seems evident from several studies that intracellular cAMP levels are lowered in established cell lines of neural origin when cells become persistently infected with measles virus and that these effects presumably are caused by alterations of plasma membrane receptors. Thus, a rat glioma cell line (C-6) persistently infected with an SSPE-derived measles virus strain demonstrated only about half the maximum values of intracellular cAMP of the uninfected cells and drastically reduced adenylate cyclase activity. ${ }^{80}$ It was stated that the measles virus infection caused impairment of the membrane receptor signal transfer. Whether the virus infection also affected the $\beta$ receptor itself was not demonstrated, although this cannot be excluded. In addition, studies on persistently infected C- 6 cells have revealed that closely related viruses (measles and canine distemper viruses) may influence cellular membrane functions in different ways. With both viruses a reduction of adenylate cyclase activity is seen, but a decrease in the number or affinity of the $\beta$ adrenergic receptor is clearly observed only after the canine distemper virus infection. ${ }^{81}$ Some of the virus-induced effects on neural cell receptor functions are summarized in Table I. 


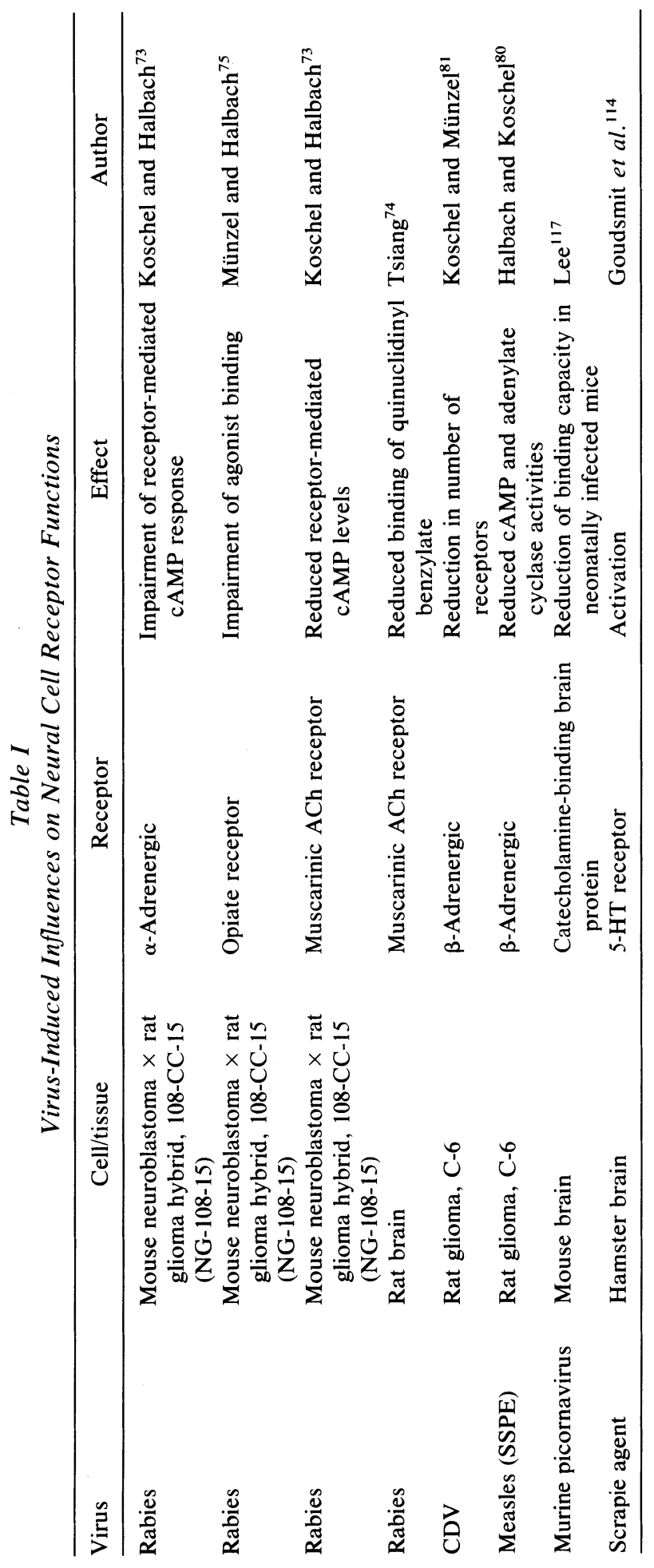




\section{VIRUS-INDUCED CHANGES IN CELLULAR PERMEABILITY AND ELECTROPHYSIOLOGY}

Permeability changes might be secondary to viral effects on the cytoskeleton of the cell and have consequences for various cell functions and, ultimately, cell vitality. Viral influences on microfilament structures of cells are manifested in alterations of the distribution of actin and myosin. ${ }^{82-84}$ Viral modulation of nerve cell microfilament structures has been studied in rat (B 103) neuroblastoma cells where the HSV-1-induced disorganization of contractile protein ${ }^{85}$ was demonstrated by the random alignment of actin cables and loss of the fibrous appearance of the myosin. Obviously, such changes might result in reduced stability and leakage through the plasma membrane. A ${ }^{51} \mathrm{Cr}$-permeability test has been used as an approach to characterize virusinduced plasma membrane changes. ${ }^{86}$ Although the results reported varied with respect to which viruses and cells were studied, there seemed to be a reduced plasma membrane permeability to ${ }^{51} \mathrm{Cr}$ in most cell types infected with HSV1. Other viruses associated with induction of dysfunctions in ion transport through membranes of infected cells were poliovirus, other picornaviruses ${ }^{87-}$ ${ }^{89}$ and Sindbis virus. ${ }^{90}$ However, of greater interest are the more specific changes in permeability induced by some virus infections.

Experiments with paramyxoviruses, the Sendai and Newcastle disease viruses, have revealed that the fusion of viral envelope and cell plasma membrane introduces hydrophilic channels into the cell membrane. ${ }^{91,92}$ As a result there are currents of low-molecular-weight compounds including ions $\left(\mathrm{Na}^{+}\right.$ and $\left.\mathrm{K}^{+}\right)$into and out of the cells. Divalent cations $\left(\mathrm{Ca}^{2+}\right)$ can specifically and reversibly prevent these effects ${ }^{93,94}$ and the virally induced channels have been considered to resemble intercellular communicating junctions. The channels are opened by removal of $\mathrm{Ca}^{2+}$ and closed when $\mathrm{Ca}^{2+}$ is added. ${ }^{94}$ The permeability changes induced by adsorption of Sendai virus were observed with both brain cells and nonneuronal cells.

A decline in cellular $\mathrm{K}^{+}$has been noted with VSV-infected L cells at 7 hr postinfection. This alteration was not associated with virus-induced inhibition of cellular protein synthesis, ${ }^{95}$ suggesting that blocking of cell metabolism by the virus and impaired cellular stability occurred independently of each other.

Specific changes of electrical parameters related to virus-induced alterations in plasma membrane permeability have previously been suggested for HSV-infected heart cells. ${ }^{96,97}$ The transmembrane ionic currents, action potentials, and electrical excitability of nerve cells are functions presumably sensitive to virus-induced membrane changes. Only a few studies of the electrophysiology of virus-infected neurons have been reported. Dissociated dorsal root ganglionic neurons of the rat responded after $4 \mathrm{hr}$ of HSV-1 infection with a decreased spike rate and lowered amplitude and overshoot. ${ }^{98}$ The full width of spikes at half-maximum and the resting membrane potential were increased. At $16 \mathrm{hr}$ postinfection, when virus-induced morphological changes first appeared in the culture, less than half of the neurons in the culture demonstrated 
an action potential. A similar study ${ }^{99}$ with HSV-2-infected guinea pig dorsal root ganglionic cells cultured in vitro also demonstrated a decrease in membrane excitability. The changes observed were explained in both studies as resulting from specifically altered ionic currents leading to reduction of $\mathrm{Na}^{+}$conductance at an early stage of the infection, although changed depolarization conditions were among the other possibilities discussed. ${ }^{98}$ One further type of electrophysiological alteration has been detected in HSV-2-infected neurons. ${ }^{100}$ Rat dorsal root ganglionic neurons generate action potentials spontaneously upon HSV-2 infection. This activity was initially of low amplitude and with low-frequency discharges but increased with time postinfection. The waveform of the spontaneous potentials seemed identical to that of the evoked action potentials from the same cells. HSV-2 infection thus seems able to cause two $\mathrm{Na}^{+}$conductance-related effects, one of which suggested a reduced $\mathrm{Na}^{+}$channel activity and the other an increased movement presumably in another part of the infected cell.

\section{TURNOVER OF NEUROTRANSMITTERS IN VIRUS- INFECTED NEURAL CELLS}

Apparently, in vitro virus infections can provoke alterations of cholinergic neurotransmission and alter the catabolism of ACh. There are also indications that in animals, defects of $\mathrm{ACh}$ metabolism might appear subsequent to virus infections. ${ }^{77,78}$

In mice intracerebrally inoculated with HSV-1, an increased turnover of brain monoamines has been observed during the acute stage of the infection by demonstration of high levels of homovanillic acid (HVA) and 5-hydroxyindoleacetic acid (5-HIAA). ${ }^{101}$ The rises of HVA and 5-HIAA brain concentrations were associated with unchanged levels of dopamine (DA) and 5-hydroxytryptamine (5-HT), but dose-response relationships, normalization of the brain concentrations by use of inhibitors of virus replication, as well as results with hydroxylation inhibitors [ $\alpha$-methyltyrosine, $p$-chlorophenylalanine, 2-(4methyl-1-homopiperazinylthiocarbonyl)disulfide] all suggested a causality between the virus infection and the increase in monoamine turnover. Effects observed after administration of probenecid, pargyline, or reserpine to HSVinfected animals indicated that neither impaired elimination of metabolites nor reduced capacity of uptake of amines was of significant influence on the concentrations of the acids. ${ }^{102}$ On the other hand, there seemed to be an increased release and turnover of catecholamines and 5-HT in the virus-infected mouse brain. This assumption was corroborated by results obtained with precursors (levodopa and 5-HTP), receptor agonists (apomorphine, clonidine), and antagonists (pimozide, phenoxybenzamine). ${ }^{103}$

Enzymatic activities related to synthesis of putative transmitter substances have also been studied in HSV-infected rats injected stereotactically into the left neostriatum. ${ }^{104}$ Choline acetyltransferase, glutamic acid decarboxylase (GAD), and tyrosine hydroxylase (TH) activities decreased in the ipsilateral neostriatum, GAD and $\mathrm{TH}$ decreased in the ipsilateral pallidum and/or sub- 
stantia nigra regions, but levels in the cerebral cortex were unchanged. It is noteworthy that in rats displaying diminished enzymatic activities upon infection, the reduced biosynthesis is correlated to severe nerve terminal destruction and to other morphological changes in cholinergic and catecholaminergic regions. ${ }^{104}$ However, in the mouse model with signs of an increased turnover of transmitters, the histopathological picture demonstrates neuronal destruction in other parts of the brain excluding the lower brain-stem area. Histofluorometry has indicated that in the infected mice, the monoaminergic neurons are essentially intact. ${ }^{101}$

Similar results were achieved with Venezuelan equine encephalomyelitis virus (VEEV), an alfa-togavirus that stimulates DA and 5-HT brain metabolism in the mouse. This influence was manifested by increased brain DA, 5-HT, and HVA levels. ${ }^{105}$ In the VEEV-infected rat, on the other hand, decreased $\mathrm{TH}^{106}$ and $\mathrm{GAD}^{107}$ activities were found.

Infection of neonatal rats with LCMV results in immunologically mediated necrotic lesions of the cerebellar cortex. Concomitant elevation of the activity of catechol-O-methyltransferase and production of normetanephrine but not that of monoamine oxidase are demonstrable. These alterations were interpreted as consequences of immune-mediated cellular infiltrate rather than changes in activity of brain parenchymal cells. ${ }^{108}$ Intracerebral inoculation of Newcastle disease virus into mice that are in a depressed metabolic state with low body temperature produces uptake and release characteristics of putative neurotransmitters that are not different from those of matched uninfected controls. ${ }^{109}$

It has been suggested that some of the virally induced behavioral consequences may be secondary to altered turnover of brain monoamines. ${ }^{103,110,111}$ Among behavioral changes of $\mathrm{HSV}$-infected mice, hyperactivity and aggressiveness appearing shortly after infection have been attributed to an increased turnover of catecholamines, ${ }^{103,111}$ whereas decreased locomotor activity and low responsiveness to catecholaminergic drugs in mice having passed the acute stage of the CNS infection were considered to reflect a reduced turnover. ${ }^{111}$ These latter observations are in agreement with a higher sensitivity to $d$-amphetamine sulfate of intracerebrally inoculated mice by day 2 postinfection and a reduced responsiveness to the drug in infected and partly immune mice examined at a later stage postinfection. ${ }^{112}$

Reduction of 5-HT brain concentrations has also been noted in scrapieinfected animals during the late clinical phase. ${ }^{113}$ Infected animals exhibited hypersensitivity reactions to $l-5$-hydroxytryptophan and to a 5-HT agonist, quipazine maleate. ${ }^{114}$ As seen in infections with conventional viruses, the behavioral effects of scrapie encephalopathy seemed dependent on genetic properties of the agent as well as genetic qualities of the host. ${ }^{115}$

These and other observations ${ }^{116,117}$ suggest varying effects of viral CNS infections on neurotransmitter synthesis dependent not only on the virus but also on the species and age of the experimental animals studied. Generally, viral CNS infections occurring in the neonatal period of the mouse seem to lead to sequelae with impairment of neurotransmitter synthesis, whereas increased turnover is seen in acutely infected adult animals. 
Virus infections have been used to modify animal CNS models. A consistent and reproducible granuloprival hypoplasia of newborn hamster cerebellum is produced by intracerebral inoculation of feline or rat parvoviruses. ${ }^{118-}$ ${ }^{120}$ Studies on these animals have provided evidence for the presence of glutamic acid as a neurotransmitter in granule cells of the cerebellum.

\section{VIRUS-INDUCED DEMYELINATION}

There are principally two kinds of reactions by which virus infections may induce demyelination: (1) viruses may infect oligodendrocytes and Schwann cells and cause demyelination by cytocidal effects on myelinating cells, and (2) virus infections may initiate reactions resulting in an immunopathologically based demyelination. Several experimental models have been elaborated for evaluation of underlying mechanisms, ${ }^{121}$ and for some of the systems pathogenetically important factors have been elucidated although the medical importance of virus-induced demyelination is still obscure.

The JHM virus is an endogenous coronavirus of the mouse causing lesions with demyelination if intracerebrally inoculated in low doses into 4-week-old mice, ${ }^{122}$ the dosage of virus and the age of the animals being decisive for the induction of demyelination. Oligodendrocytes are apparently the main target cells and demonstrate morphological and functional abnormalities associated with myelin degradation and membrane vesiculation. ${ }^{123-126}$ The demyelination caused by the infection seems fundamentally dependent on the cytocidal effects of the virus.

In infections with measles, canine distemper virus (CDV), or other paramyxoviruses, development of a demyelinating disease as a direct consequence of cytopathogenic viral effects seems unlikely. Viral components in measles ${ }^{2,127}$ or CDV infections ${ }^{128}$ are rarely seen in oligodendrocytes, but the presence of inflammatory cells in areas of demyelination, in both acute and chronic types of infection, suggests immunopathological reactions. Intriguing is the late-appearing demyelination demonstrable in mice experimentally infected with murine picornavirus (Theiler virus). The acute infection resembling poliomyelitis is followed 2-3 weeks later by a disease characterized by spinal cord myelin destruction and mononuclear cell infiltration. ${ }^{129}$ Nerve cell infection predominates during the acute poliomyelitis-like phase and, as with other picornaviruses, the infected cells undergo a cytolytic degeneration. The demyelination appearing at later stages can be prevented by immunosuppression, i.e., by treatments with cyclophosphamide and rabbit anti-mouse thymocyte serum. ${ }^{130}$ No viral antigens are detectable in Schwann cells but are abundant in neurons, astrocytes, and macrophages. ${ }^{131}$ Remyelinating Schwann cells may be seen invading the demyelinated lesions.

A similar process of remyelination can be observed in HSV-infected mice suffering from a demyelinating process in the transitional area of the trigeminal nerve where the central and peripheral nervous systems meet. ${ }^{132,133}$ Both oligodendrocytes and astrocytes ${ }^{133,134}$ display signs of infection. It has been suggested that the astrocytes, which are amply supplied with HSV receptors, ${ }^{15}$ 
may be the cells responsible for transferring the axoplasmically transported infection from the axolemmal membrane of Ranvier nodes to the myelinating cells. ${ }^{134}$ Myelin destruction shortly after the inoculation of HSV might indicate that cytocidal effects of the virus are of importance for the initiation of the demyelinating process, ${ }^{133,135}$ whereas host inflammatory responses seem essential for its maintenance. ${ }^{136,137}$ Thus, the reduction of the mononuclear infiltrate appears concomitantly with reduced demyelination in cyclophosphamide-treated ${ }^{137}$ and in T-cell-deficient mice. ${ }^{138}$

In Semliki forest virus-infected animals demonstrating destruction of oligodendrocytes $^{139}$ as well as an immunologically monitored demyelination, the remyelination of initially relatively mild lesions seems to be inhibited. ${ }^{140,141}$ Possibly, the immunopathological reactions may be maintaining the demyelination by interfering with the processes of remyelination.

The immunological mechanisms by which various virus infections create myelin-destructive reactions are still unknown. Viral antigens might be absent in plaques of demyelination. Some antigenic relatedness has been noted between measles virus protein and myelin basic protein, ${ }^{142}$ but such virus-myelin antigenic similarities can hardly account for demyelination with all viruses involved. It has been shown that recurrent exposures of the CNS to viral antigens can exacerbate experimental allergic encephalomyelitis in guinea pigs immunized with spinal cord myelin. ${ }^{143}$ One theory has suggested that macrophagederived substances such as proteases of inflammatory immune reactions against viral antigens of infected CNS cells may be responsible for the injuries of the myelinated tissue. ${ }^{144,145} \mathrm{~A}$ pattern for possible collaboration of various reactions in development and maintenance of virus-induced demyelination is presented in Fig. 1.

\section{INFLUENCES OF THE CNS AND NEURAL CELLS ON VIRUS INFECTIONS}

The impacts of virus infections on CNS structures and functions have been discussed above. However, the progress and outcome of the virus infections themselves are also subject to modification by factors and functions intrinsic to the nervous system. Aspects of these influences include restriction of viral replication in neural cells, host-modified spread and expression of virulence, and development of persistent and latent virus infections.

HSV synthesizes its own thymidine kinase, perhaps an essential ability for a virus that might have to replicate in neuronal cells with low DNA-synthesizing activity. The replication of thymidine kinase-negative HSV mutants is restricted in sensory ganglia of infected animals ${ }^{146-148}$ and in ganglia cultured in vitro. ${ }^{149}$ Whether this phenomenon is due to insufficient capacity of neurons to provide phosphorylated thymidine derivatives is not known. Restriction of HSV replication in neural cells has been attributed to lack of synthesis of a necessary gene product. ${ }^{150-152}$ and also to the presence in neural cells of virusinhibiting non-interferon factors. ${ }^{153}$ Undoubtedly, the HSV infection can vary 


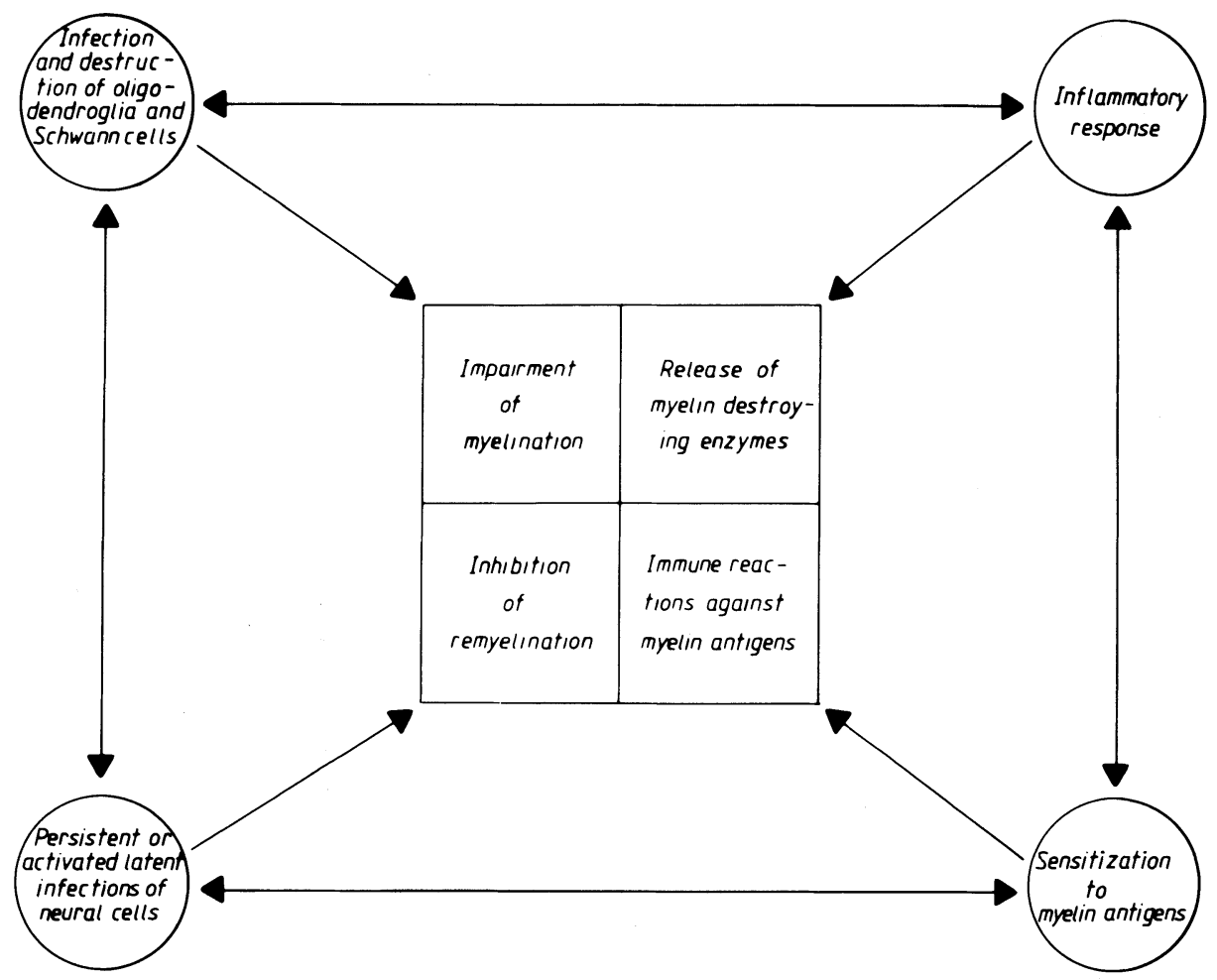

Fig. 1. Virus-induced reactions associated with development and maintenance of demyelination.

considerably in neural cells from permissive infections to a relatively low degree of permissiveness, depending on the species origin of the cells studied. ${ }^{150}$

It is well recognized that the integrity of postganglionic axons influences the HSV ganglionic infection. Neurectomy in mice with a ganglionic infection reactivates latent $\mathrm{HSV}$ infection ${ }^{154,155}$ and favors the viral replicative phase over that of latency. Both mechanical ${ }^{156}$ and electrical stimulations ${ }^{157}$ of the nerve induce reactivation of latent infections with shedding of virus. 6-Hydroxydopamine-induced destruction of adrenergic nerve terminals enhances HSV replication in ganglion cells. ${ }^{158}$ Thus, virus produced in the superior cervical ganglion of mice was augmented when the drug was administrated 2 days after infection. It was suggested that injury to the terminal part of the axon directly influenced viral replication in the neuronal soma.

In cultures of rat dorsal ganglion neurons, the time course of HSV infection is altered in the presence of antiviral antibody ${ }^{56}$ but despite antibody concentration adequate to neutralize the virus, spread of the infection from neuron to neuron cannot be prevented. Also, HSV infection in mice is greatly influenced by immune reactions shunting the infection from an acute productive to a nonproductive stage. ${ }^{159,160}$ The precise role of the immune reactions in establishment of latency is not known but in the immune individual it is probably only within the neuronal network of the CNS that the infection may be spread and maintained. In no other cells but neurons has establishment of latent HSV 
infections been unequivocally shown. In peripheral tissues, persistent infections are maintained by virus-productive infections. ${ }^{161}$

Reduction of HSV replication occurred when intracellular levels of cAMP were raised, whereas enhanced viral production was the rule when cellular cGMP concentrations were increased. ${ }^{162}$ Possibly, changes in intracellular cyclic nucleotides represent parts of a cellular control mechanism of HSV replication. Other observations suggest that cyclic nucleotides might also be involved in cellular control of the latent infection. ${ }^{163}$ The existence of control mechanisms of cyclic nucleotides for selection of gene expression leading to induction of viral replication in somatic cell hybrids carrying but not expressing EBV genomes has been described. ${ }^{164}$

Conversion of productive measles virus infection in neural cells to low or nonproductive infections may be achieved by treatment with drugs capable of modifying cyclic nucleotide metabolism. ${ }^{165,166}$ Thus, inhibition of cAMP phosphodiesterase via papaverine-increased cAMP levels reduces viral replication concomitantly with the abolishment of viral matrix (M) protein. Absence of $\mathbf{M}$ protein in measles virus-infected cells is considered an important pathogenetic feature of SSPE ${ }^{167,168}$ and is also demonstrable in experimental models of measles virus persistency. ${ }^{169}$ Effects on measles virus replication by changes in cyclic nucleotide metabolism have been observed not only with neural cells but also in a nonneural cell system, i.e., in human amnionic cells. ${ }^{165}$ As for HSV-infected cells, addition of cGMP to measles virus-infected neural cells counteracts the influence of raised cAMP levels. The observations reported suggest that evolution of an acute measles virus infection to a persistent type of infection might be influenced if not regulated via the cyclic nucleotides.

In contrast to nonneural cells, neurons sustain replication of VSV with relatively maintained integrity. ${ }^{170}$ This morphological stability seems to be associated with cellular maturity and increases gradually with the stage of neuronal differentiation. However, the preservation of neuronal cells seems in addition dependent on the presence in the inoculum of defective interfering virus particles. ${ }^{170,171}$ It is not known if in infection of neural cells the production of defective virus particles is enhanced relative to that of virus infections of cells of nonneural origin, although this has been suggested. ${ }^{170}$ Interference with VSV replication by defective virus occurs in the neuron as in the nonneural cell at the level of viral replication. In this context, it should be recalled that virus-induced interferon production seems to parallel and stimulate cellular prostaglandin secretion. ${ }^{172-174}$ Prostaglandins restore the antiviral reactivity of interferon in hyporeactive animals ${ }^{175}$ and regulate cAMP enhancement of interferon. ${ }^{176,177}$

\section{CONCLUDING REMARKS}

Morphological studies on the virus-infected CNS have revealed the particular affinity of some viruses for neural cells and emphasize the predilection of neurotropic viruses for different CNS structures. Viral neurotropism can be discussed in terms of occurrence and density of viral receptors on neural cells 
and axonal transport of the infection. In recent years, progress in the delineation of molecular events involved in virus-induced functional changes of infected nerve cells is discernible although many of the virus-nerve cell interactions cannot as yet be explained neurochemically. There is also a growing interest in the various mechanisms by which the nervous system is able to modify the outcome of virus infections. The findings discussed in this chapter have mainly been gathered by studies on experimental animals or neural cell cultures, but their medical implications are essentially unexplored. There are reasons to believe, however, that virus-induced CNS dysfunctions might be of greater medical importance in neurology and psychiatry than is recognized today. Finally, certain functions of the brain may be advantageously studied on the virusinfected animal since virus infections specifically infect particular cell populations or compartments of the CNS, providing a model otherwise difficult to achieve.

AcKnowledgment. The author acknowledges support by the Swedish Medical Research Council (Grant 4514).

\section{REFERENCES}

1. Murphy, F. A., 1977, Arch. Virol. 54:279-297.

2. Dubois-Dalcq, M., 1979, Int. Rev. Exp. Pathol. 19:101-135.

3. Fields, B. N., and Weiner, H. L., 1982, Life Sciences Research, Report 20 (T. A. Sears, ed.), Springer-Verlag, Berlin, pp. 217-228.

4. Johnson, R. T., 1982, Viral Infections of the Nervous System, Raven Press, New York.

5. Klein, R. J., 1982, Arch. Virol. 72:143-168.

6. Stroop, W. G., And Baringer, J. R., 1982, Progress of Medical Virology, Volume 28 (J. L. Melnick, ed.), Karger, Basel, pp. 1-43.

7. Bannister, L H., 1976, The Peripheral Nerve (D. N. London, ed.), Chapman and Hall, London, pp. 396-454.

8. Halata, Z., 1977, J. Anat. 124:717-729.

9. Persson, L. A., and Kristensson, K., 1979, Acta Neuropathol. 46:191-196.

10. Broadwell, R. D., and Brightman, M. W., 1979, J. Comp. Neurol. 185:31-74.

11. Holtzman, E., 1977, Neuroscience 2:327-355.

12. Kristensson, K., 1978, Annu. Rev. Pharmacol. Toxicol. 18:97-110.

13. Ellisman, M. H., and Lindsey, J. D., 1982, Axoplasmic Transport (D. G. Weiss, ed.), Raven Press, New York, pp. 55-63.

14. Vahlne, A., Svennerholm, B., and Lycke, E., 1979, J. Gen. Virol. 44:217-225.

15. Vahlne, A., Nyström, B., Sandberg, M., Hamberger, A., and Lycke, E., 1978, J. Gen. Virol. 40:359-371.

16. Tardieu, M., and Weiner, H. L., 1982, Science 215:419-421.

17. Vahlne, A., Svennerholm, B., Sandberg, M., Hamberger, A., and Lycke, E., 1980, Infect. Immun. 28:675-680.

18. Ziegler, R. J., and Herman, R. E., 1980, Infect. Immun. 28:620-623.

19. Spear, P. G., 1980, Cell Membrane and Viral Envelopes, Volume 2 (H. A. Blough and J. M. Tiffany, eds.), Academic Press, New York, pp. 709-750.

20. Lonberg-Holm, K., and Philipson, L., eds., 1981, Virus Receptors, Part 2, Animal Viruses, Chapman and Hall, London.

21. Roizman, B., 1962, Proc. Natl. Acad. Sci. U.S.A. 48:973-977.

22. Roizman, B., 1962, Proc. Natl. Acad. Sci. U.S.A. 48:795-803.

23. Okada, Y., and Kim, J., 1972, Virology 50:507-515. 
24. Ito, M., and Barron, A. L., 1974, J. Virol. 13:1312-1318.

25. Ziegler, R. J., and Pozos, R. S., 1981, Infect. Immun. 34:588-595.

26. Steindler, D. A., 1981, Brain Res. 223:367-373.

27. Carbonetto, S., and Argon, Y., 1980, Dev. Biol. 80:364-378.

28. Murphy, F. A., Bauer, S. P., Harrison, A. K., and Winn, W. C., 1973, Lab. Invest. 28:261376.

29. Harrison, A. K., and Murphy, F. A., 1978, Arch. Virol. 57:167-175.

30. Watson, H. D., Tignor, G. H., and Smith, A. L., 1981, J. Gen. Virol. 56:371-382.

31. Lentz, T. L., Burrage, T. G., Smith, A. L., Crick, J., and Tignor, G. H., 1982, Science 215:182-184.

32. Smith, A. L., and Tignor, G. H., 1980, Arch. Virol. 66:11-26.

33. Haywood, A. M., 1974, J. Mol. Biol. 83:427-436.

34. Haywood, A. M., 1975, Negative, Strand Viruses, Volume 2 (B. W. J. Mahy and R. D. Berry, eds.), Academic Press, New York, pp. 923-928.

35. Wu, P.-S., Ledeen, R. W., Udem, S., and Isaacson, Y. A., 1980, J. Virol. 33:304-310.

36. Holmgren, J., Svennerholm, L., Elwing, H., Fredman, P., and Strannegård, Ö., 1980, Proc. Natl. Acad. Sci. U.S.A. 77:1947-1950.

37. Markwell, M. A. K., and Paulson, J. C., 1980, Proc. Natl. Acad. Sci. U.S.A. 77:5693-5697.

38. Markwell, M. A. K., Svennerholm, L., and Paulson, J. C., 1981, Proc. Natl. Acad. Sci. U.S.A. 78:5406-5410.

39. Fried, H. T., Cahan, L. D., and Paulson, J. C., 1981, Virology 109:188-192.

40. Gibson, R., Kornfeld, S., and Schlesinger, S., 1980, Trends Biochem. Sci. 5:290-293.

41. Svennerholm, B., Olofsson, S., Lundén, R., Vahlne, A., and Lycke, E., 1982, J. Gen. Virol. 63:343-349.

42. Gibson, R., Leavitt, R., Kornfeld, S., and Schlesinger, S., 1978, Cell 13:671-679.

43. Dore-Duffy, P., and Howe, C., 1978, Proc. Soc. Exp. Biol. Med. 157:622-625.

44. Leavitt, R., Schlesinger, S., and Kornfeld, S., 1977, J. Virol. 21:375-385.

45. Nakamura, K., and Compans, R. W., 1978, Virology 84:303-319.

46. Bodian, D., and Howe, H. A., 1941, Bull. Johns Hopkins Hosp. 69:79-85.

47. Hammerschlag, R., and Stone, G. C., 1982, Trends Neurosci. 5:12-15.

48. Kristensson, K., Lycke, E., and Sjöstrand, J., 1971, Acta Neuropathol. 17:44-53.

49. Hill, T. J., Field, H. J., and Roome, A. P. C., 1972, J. Gen. Virol. 15:253-255.

50. Cook, M. L., and Stevens, G., 1973, Infect. Immun. 7:272-288.

51. Schwartz, J., and Elizan, T. S., 1973, J. Neuropathol. Exp. Neurol. 32:303-312.

52. Schwartz, J., and Elizan, T. S., 1975, J. Neuropathol. Exp. Neurol. 34:359-368.

53. Fenyves, A., and Strupp, L., 1982, Intervirology 17:228-239.

54. Bak, I. J., Markham, C. H., Cook, M. L., and Stevens, J. G., 1977, Brain Res. 136:415-429.

55. Kristensson, K., Nennesmo, I., Persson, L., and Lycke, E., 1982, J. Neurol. Sci. 54:149156.

56. Price, R. W., Rubenstein, R., and Khan, A., 1982, Arch. Virol. 71:127-140.

57. Murphy, F. A., Harrison, A. K., Winn, W. C., and Bauer, S. P., 1973, Lab. Invest. 29:116.

58. Bijlenga, G., and Heaney, T., 1978, J. Gen. Virol. 39:381-385.

59. Tsiang, H., 1979, J. Neuropathol. Exp. Neurol. 38:286-296.

60. Iwasaki, Y., and Clark, H., 1975, Lab. Invest. 33:391-399.

61. Dubois-Dalcq, M., Hooghe-Peters, E. L., and Lazzarini, R. A., 1980, J. Neuropathol. Exp. Neurol. 39:507-522.

62. Van Pottelsberghe, C., Rammohan, K. W., McFarland, H. F., and Dubois-Dalcq, M., 1979, Lab. Invest. 40:99-108.

63. Esiri, M. M., Oppenheimer, D. R., Bradnell, B., and Haire, M., 1981, J. Neurol. Sci. 53:2943.

64. Budka, H., Lassman, H., and Popow-Kraupp, T., 1982, Acta Neuropathol. 56:52-62.

65. Haase, A. T., Swoveland, P., Stowring, L., Ventura, P., Johnson, K. P., Norrby, E., and Gibbs, C. J., Jr., 1981, J. Infect. Dis. 144:154-160.

66. Goldstein, J. L., Anderson, R. G. W., and Brown, M. S., 1979, Nature 279:679-685.

67. Dubois-Dalcq, M., and Rentier, B., 1980, Progress of Medical Virology, Volume 26 (J. L. Melnick, ed.), Karger, Basel, pp. 158-213. 
68. Oldstone, M. B. A., Fujinami, R. S., and Lampert, P. W., 1980, Progress of Medical Virology, Volume 26 (J. L. Melnick, ed.), Karger, Basel, pp. 45-93.

69. Raff, M., 1976, Nature 259:265-266.

70. Heineman, S., Merlie, J., and Lindstrom, J., 1978, Nature 274:65-67.

71. Schechter, Y., Hernsey, L., Schlessinger, J., and Cuatrecasas, P., 1979, Nature 278:835838.

72. Hamprecht, B., 1977, Int. Rev. Cytol. 49:99-170.

73. Koschel, K., and Halbach, M., 1979, J. Gen. Virol. 42:627-632.

74. Tsiang, H., 1982, J. Gen. Virol. 61:277-281.

75. Münzel, P., and Koschel, K., 1981, Biochem. Biophys. Res. Commun. 101:1241-1250.

76. Tsiang, H., and Guillon, J. C., 1981, Acta Neuropathol. 55:263-267.

77. Oldstone, M. B., Holmstoen, J., and Welsh, R. M., Jr., 1977, J. Cell. Physiol. 91:459-471.

78. Lundén, R., Vahlne, A., and Lycke, E., 1980, Proc. Soc. Exp. Biol. Med. 165:55-62.

79. Miller, C. A., Erlich, S., and Raine, C. S., 1981, Life Sci. 29:2473-2480.

80. Halbach, M., and Koschel, K., 1979, J. Gen. Virol. 42:615-619.

81. Koschel, K., and Muenzel, P., 1980, J. Gen. Virol. 47:513-517.

82. Fagraeus, A., Tyrell, D. L. J., Norberg, R., and Norrby, E., 1978, Arch. Virol. 57:291-296.

83. Meyer, R. K., Burger, M. M., Tschannen, R., and Schäfer, R., 1981, Arch. Virol. 67:11-18.

84. Lösse, D., Lauer, R., Veder, D., and Radsak, K., 1982, Arch. Virol. 71:353-359.

85. Winkler, M., Dawson, G. J., Elizan, T. S., and Berl, S., 1982, Arch. Virol. 72:95-103.

86. Schlehofer, J. R., Habermehl, K.-O., Diefenthal, W., and Hampl, H., 1979, Intervirology 11:158-166.

87. Nair, N., 1981, J. Virol. 37:268-273.

88. Carrasco, L., and Smith, A. E., 1976, Nature 264:807-809.

89. Egberts, E., Hackett, P. B., and Traub, P., 1977, J. Virol. 22:591-597.

90. Garry, R. F., Bishop, J. M., Parker, S., Westbrook, K., Lewis, G., and Waite, M. 'R. F., 1979, Virology 96:108-120.

91. Foster, K. A., Gill, K., Micklem, K. J., and Pasternak, C. A., 1980, Biochem. J. 190:639646.

92. Poste, G., and Pasternak, C. A., 1978, Cell Surface Rev. 5:305-367.

93. Impraim, C. C., Foster, K. A., Micklem, K. J., and Pasternak, C. A., 1980, Biochem. J. 186:847-860.

94. Micklem, K. J., and Pasternak, C. A., 1982, J. Physiol. (London) 326:11P.

95. Francoeur, A. M., and Stanners, C. P., 1978, J. Gen. Virol. 39:551-554.

96. Batra, G. K., Nahmias, A. J., and De Haan, R. L., 1976, Nature 259:677-678.

97. Shrier, A., Nahmias, A. J., and De Haan, R. L., 1978, Am. J. Physiol. 234:170-176.

98. Oakes, S. G., Petry, R. W., Ziegler, R. J., and Pozos, R. S., 1981, J. Neuropathol. Exp. Neurol. 40:380-389.

99. Fukuda, J., and Kurata, T., 1981, Brain Res. 211:235-241.

100. Lima, P. H., Oakes, S. G., Pozos, R. S., and Ziegler, R. J., 1981; International Workshop on Herpesviruses, Esculapio, Bologna, p. 158 (abstract).

101. Lycke, E., Modigh, K., and Roos, B.-E., 1970, Brain Res. 23:235-246.

102. Lycke, E., and Roos, B.-E., 1972, Brain Res. 44:603-613.

103. Lycke, E., and Roos, B.-E., 1974, J. Neurol. Sci. 22:277-289.

104. Kataoka, K., Bak, I. J., and Markham, C. H., 1979, Brain Res. 169:401-405.

105. Bonilla, E., Ryder, S., and Hernandez, H., 1975, J. Neurochem. 25:529-530.

106. Levine, S., Bonilla, E., Ryder, S., Salazar, M., and Rangel, P., 1981, Neurochem. Res. 6:691697.

107. Bonilla, E., Ryder, E., and Ryder, S., 1980, Neurochem. Res. 5:209-215.

108. Guchhait, R. B., and Monjan, A. A., 1980, Neuroscience 5:1105-1111.

109. Bondy, S. C., Burks, J. S., and Harrington, M. E., 1979, Arch. Neurol. 36:540-543.

110. Lycke, E., Modigh, K., and Roos, B.-E., 1969, Experientia 25:951-953.

111. Seegal, R., Sikora, E., and Hotchin, J., 1980, Pharmacol. Biochem. Behav. 12:61-66.

112. Seegal, R., Hotchin, J., and Sikora, E., 1981, Life Sci. 29:777-782.

113. Rohwer, R. G., Neckers, L. M., Trepel, J. B., Gajdusek, D. C., and Wyatt, R. J., 1981, Brain Res. 220:367-371. 
114. Goudsmit, J., Rohwer, R. G., Silbergeld, E. K., and Gajdusek, D. C., 1981, Brain Res. 220:372-377.

115. McFarland, D. J., Baker, F. D., and Hotchin, J., 1980, Physiol. Behav. 24:911-914.

116. Lycke, E., and Roos, B.-E., 1975, J. Neurol. Sci. 26:49-60.

117. Lee, C. J., 1975, Pediatr. Res. 9:645-652.

118. Herndon, R. M., Margolis, G., and Kilham, L., 1971, J. Neuropathol. Exp. Neurol. 30:196205.

119. Young, A. B., Oster-Granite, M. L., Herndon, R. M., and Snyder, S. H., 1974, Brain Res. 73:1-13.

120. Snyder, S. H., Young, A. B., Oster-Granite, M. L., and Herndon, R. M., 1975, Metabolic Compartmentation and Neurotransmission: Relation to Brain Structure and Function (S. Berl, D. D. Clarke, and D. Schneider, eds.), Plenum Press, New York, pp. 1-10.

121. Dal Canto, M. C., and Rabinowitz, S. G., 1982, Ann. Neurol. 11:109-127.

122. Weiner, L. P., 1973, Arch. Neurol. 28:298-303.

123. Powell, H. C., and Lampert, P. W., 1975, Lab. Invest. 33:440-445.

124. Fleury, H. J. A., Sheppard, R. D., Bornstein, M. B., and Raine, C. S., 1980, Neuropathol. Appl. Neurobiol. 6:165-179.

125. Knobler, R. L., Dubois-Dalcq, M., Haspel, M. V., Claysmith, A. P., Lampert, P. W., and Oldstone, M. B. A., 1981, J. Neuroimmunol. 1:81-92.

126. Takahashi, K., Goto, N., Ishida, T., Katami, K., and Fujiwara, K., 1981, Jpn. J. Exp. Med. 51:323-330.

127. Raine, C. S., Prineas, J. W., Sheppard, R. D., Bornstein, M. B., and Dubois-Dalcq, M., 1977, J. Neurol. Sci. 33:13-20.

128. Wisniewski, H., Raine, C. S., and Kay, W. J., 1972, Lab. Invest. 26:589-599.

129. Lipton, H. L., 1975, Infect. Immun. 11:1147-1155.

130. Lipton, H. L., and Dal Canto, M. C., 1976, Science 192:62-64.

131. Dal Canto, M. C., 1982, Infect. Immun. 35:1133-1138.

132. Townsend, J. J., and Baringer, J. R., 1976, J. Neuropathol. Exp. Neurol. 35:100.

133. Kristensson, K., Vahlne, A., Persson, L. A., and Lycke, E., 1978, J. Neurol. Sci. 35:331340 .

134. Townsend, J. J., 1981, J. Neuropathol. Exp. Neurol. 40:369-379.

135. Kristensson, K., Svennerholm, B., Persson, L., Vahlne, A., and Lycke, E., 1979, J. Neurol. Sci. 43:253-264.

136. Townsend, J. J., and Baringer, J. R., 1979, Lab. Invest. 40:178-182.

137. Kristensson, K., Svennerholm, B., Vahlne, A., Nilheden, E., Persson, L., and Lycke, E., 1982, J. Neurol. Sci. 53:205-216.

138. Townsend, J. J., 1981, J. Neurol. Sci. 50:435-441.

139. Sheahan, B. J., Barett, P. N., and Atkins, G. J., 1981, Acta Neuropathol. 53:129-136.

140. Illavia, S. J., Webb, H. E., and Pathak, S., 1982, Neuropathol. Appl. Neurobiol. 8:35-42.

141. Kelly, W. R., Blakemore, W. F., Jagelman, S., and Webb, H.E., 1982, Neuropathol. Appl. Neurobiol. 8:43-53.

142. Panitch, H. S., Swoveland, P., and Johnson, K. P., 1979, Neurology 29:548-549.

143. Hochberg, F. H., Lehrich, J. R., and Arnason, B. G. W., 1977, Neurology 27:584-587.

144. Wisniewski, H. M., 1977, Br. Med. Bull. 33:54-59.

145. Cammer, W., Bloom, B. R., Norton, W. T., and Gordon, S., 1978, Proc. Natl. Acad. Sci. U.S.A. 75:1554-1558.

146. Field, H. J., and Wildy, P., 1978, J. Hyg. 81:267-277.

147. Tenser, R. B., Miller, R. L., and Rapp, F., 1979, Science 205:915-917.

148. Tenser, R. B., and Dunstan, M. E., 1979, Virology 99:417-422.

149. Price, R. W., and Khan, A., 1981, Infect. Immun. 34:571-580.

150. Adler, R., Glorioso, J. C., and Levine, M., 1978, J. Gen. Virol. 39:9-20.

151. Rice, M., Holland, L., and Wagner, E. K., 1979, Arch. Virol. 59:345-355.

152. Levine, M., Goldin, A. L., and Glorioso, J. C., 1980, J. Virol. 35:203-210.

153. Vahlne, A., and Lycke, E., 1978, J. Gen. Virol. 39:321-332.

154. Walz, M. A., Price, R. W., and Notkins, A. L., 1974, Science 184:1185-1187.

155. Price, R. W., and Schmitz, J., 1979, Infect. Immun. 23:373-383. 
156. Nesburn, A. B., Dickinson, R., and Radnoti, M., 1976, Invest. Ophthalmol. 15:726-731.

157. Green, M. T., Rosborough, J. P., and Dunkel, E. C., 1981, Infect. Immun. 34:69-74.

158. Price, R. W., 1979, Science 205:518-520.

159. Openshaw, H., Puga, A., and Notkins, A. L., 1979, Fed. Proc. 38:2660-2664.

160. Openshaw, H., Shavrina Asher, L. V., Wohlenberg, C., Sekizawa, T., and Notkins, A. L., 1979, J. Gen. Virol. 44:205-215.

161. Scriba, M., and Tatzber, F., 1981, Infect. Immun. 34:655-661.

162. Stanwick, T. L., Anderson, R. W., and Nahmias, A. J., 1977, Infect. Immun. 18:342-347.

163. Blue, W. T., Winland, R. D., Stobbs, D. G., Kirksey, D. F., and Savage, R. E., 1981, Antimicrob. Agents Chemother. 20:547-548.

164. Zimmerman, J. E., Jr., Glazer, R., and Rapp, F., 1973, J. Virol. 12:1442-1445.

165. Robbins, S. J., and Rapp, F., 1980, Virology 106:317-326.

166. Miller, C. A., and Carrigan, D. R., 1982, Proc. Natl. Acad. Sci. U.S.A. 79:1629-1633.

167. Hall, W. W., and Choppin, P. W., 1979, Virology 99:443-447.

168. Stephensson, J. R., Siddell, S. G., and ter Meulen, V., 1981, J. Gen. Virol. 57:191-197.

169. Johnson, K. P., Norrby, E., Swoveland, P., and Carrigan, D.R., 1981, J. Infect. Dis. 144:161169.

170. Faulkner, G., Dubois-Dalcq, M., Hooghe-Peters, E., McFarland, H. F., and Kazzarini, R. A., 1979, Cell 17:979-991.

171. Clark, H. F., 1980, Infect. Immun. 27:1012-1022.

172. Yaron, M., Yaron, I., Gurani-Rotman, D., Revel, M., Linder, H., and Zor, U., 1977, Nature 267:457.

173. Fitzpatrick, F. A., and Stringfellow, D. A., 1980, J. Immunol. 125:431-437.

174. Schultz, R. M., Stoychkov, J. N., Pavlidis, N., Chirigos, M.A., and Okowski, Z. L., 1979, J. Reticuloendothel. Soc. 26:93-102.

175. Stringfellow, D., 1978, Science 201:376-378.

176. Gorman, R., 1975, J. Cyclic Nucleotide Res. 1:1-9.

177. Weber, J., and Stewart, R., 1975, J. Gen. Virol. 28:363-372.

178. Lycke, E., Kristensson, K., Svennerholm, B., Vahlne, A., and Ziegler, R., 1984, J. Gen. Virol. 65:55-64. 